PATIK : Jurnal Hukum

https://ejournal.uhn.ac.id/index.php/patik

Volume 09 Nomor 01, April 2020 Page : 1 - 9

p-issn : 2086 - 4434

\title{
ANALISIS DASAR PERTIMBANGAN HAKIM DALAM MENJATUHKAN SANKSI PIDANA PERAMPASAN ASET KORPORASI YANG MELAKUKAN PENIPUAN DAN PENCUCIAN UANG SECARA BERLANJUT (STUDI PUTUSAN NOMOR 3096 K/PID.SUS/2018)
}

\author{
Adirman Budi Ndruru, July Esther, Herlina Manullang \\ Fakultas Hukum, Universitas HKBP Nommensen \\ herlinamanullang@uhn.ac.id
}

\begin{abstract}
Abstrak
Tindak pidana yang dilakukan oleh korporasi dapat berbentuk penipuan dan pencucian uang. dalam Putusan Nomor 3096 K/Pid.Sus/2018. Adapun ketentuan perampasan aset korporasi dalam tindak pidana penipuan dan tindak pidana pencucian uang diatur dalam Pasal 39 KUHP dan Pasal 7 sampai dengan Pasal 9 Undang-Undang Nomor 8 Tahun 2010 pertimbangan hakim dalam menjatuhkan sanksi pidana perampasan aset korporasi yang melakukan tindak pidana penipuan dan tindak pidana pencucian uang secara berlanjut putusan nomor 3096/Pid.Sus/2018 didasarkan pada ketentuan Pasal 39 jo Pasal 46 jo Pasal 194 KUHAP dan berpandangan bahwa barang bukti nomor 1 sampai s/d 529.
\end{abstract}

Kata kunci: Pertimbangan Hakim, Perampasan Aset, Korporasi, Penipuan, Pencucian Uang, Pidana Berlanjut.

\begin{abstract}
Criminal acts committed by corporations can take the form of fraud and money laundering. Penalties that can be imposed on a corporation that commits a criminal act other than the main crime in the form of a fine can also be subject to additional criminal penalties in the form of "confiscation of corporate assets by the State". This type of research is normative juridical legal research and library research. The legal materials used in the writing of this thesis are arranged qualitatively and described in the form of systematically arranged sentences, discussion, interpretation and conclusions are drawn about the problems under study. The provisions for confiscation of corporate assets in criminal acts of fraud and money laundering are regulated in Article 39 of the Criminal Code and Article 7 to Article 9 of Law Number 8 Year 2010 concerning the Prevention and Eradication of Money Laundering
\end{abstract}

Keywords: Judge's Consideration, Asset Seizure, Corporation, Fraud, Money Laundering, Continuing Crime. 


\section{PATIK : JURNAL HUKUM Vol : 09 No. 1, April 2020, Hal 1 - 9}

\section{Pendahuluan}

Tenaga kerja merupakan penduduk yang berada dalam usia kerja. Menurut UU No. 13 tahun 2003 Bab I pasal 1 ayat 2 disebutkan bahwa tenaga kerja adalah setiap orang yang mampu melakukan pekerjaan guna menghasilkan barang dan atau jasa untuk memenuhi kebutuhan sendiri maupun untuk masyarakat. Sedangkan pekerja adalah setiap orang yang bekerja dengan menerima upah atau imbalan dalam bentuk lain dan perusahaan/pengusaha membutuhkan pekerja untuk melakukan pekerjaan tersebut. Demikian juga pekerja yang bekerja di perusahaan bertujuan untuk mendapatkan upah dengan demikian pengusaha bertujuan untuk mendapatkan keuntungan hubungan antara pengusaha dengan pekerja adalah hubungan yang berdasarkan hubungan kerja.

Penciptaan lapangan kerja, produk barang serta jasa yang dihasilkan dari usaha perusahaan, dan pembayaran pajak yang memberikan pendapatan bagi negara merupakan kontribusi yang dirasakan besar manfaatnya.Kontrak Kerja/Perjanjian Kerja menurut Undang-Undang No.13/2003 tentang Ketenagakerjaan adalah perjanjian antara pekerja/buruh dengan pengusaha atau pemberi kerja yang memuat syarat syarat kerja, hak, dan kewajiban para pihak.

Perusahaan dalam mempekerjakan pekerja didasarkan atas kesepakatan yang dibuat dalam perjanjian baik secara tertulis maupun denngan lisan. Hubungan antara perusahaan dengan pekerja merupakan hubungan kerja. Hubungan kerja yang berdasarkan perjanjian mengakibatnya tercipta/lahirnya hak dan kewajiban antara pekerja dan perusahaan. Contoh hak pekerja adalah hak memperoleh upah, hak mendapatkan kesempatan dan perlakuan yang sama, hak mendapatkan pelatihan kerja, hak penempatan tenaga kerja, hak memiliki waktu kerja yang sesuai, hak mendapatkan kesehatan dan keselamatan kerja, hak mendapatkan kesejahteraan, hak ikut serta dalam serikat pekerja/buruh, hak untuk cuti, hak khusus karyawan perempuan. Contoh hak pengusaha berhak sepenuhnya atas hasil kerja pekerja, berhak atas ditaatinya aturan kerja oleh pekerja, termasuk pemberian sanksi, berhak atas perlakuan yang hormat dari pekerja, berhak melaksanakan tata tertib kerja yang telah dibuat oleh pengusaha.

Hubungan kerja adalah hubungan antara pengusaha dengan pekerja berdasarkan perjanjian kerja. Sedangkan perjanjian kerja sebagaimana diatur dalam Undang-undang Nomor 13 Tahun 2003 Tentang Ketenagakerjaan yang menyebutkan perjanjian kerja merupakan suatu perjanjian dimana pihak pekerja/buruh mengikat diri untuk bekerja pada pihak pengusaha dengan menerima upah. Bentuk perjanjian kerja pada umumnya bebas dan dapat dibuat secara lisan maupun tulisan ${ }^{1}$. Khusus untuk perjanjian kerja kontra wajib dibuat secara tertulis. Untuk menyatakan suatu perjanjian kerja dianggap sah atau tidak maka wajib untuk memperhatikan ketentuan dalam pasal 52 UU ketenaga kerjaan yang merupakan cerminan dalam pasal 1320 yang menyatakan bahwa supaya terjadi persetujuan yang sah, perlu dipenuhi empat syarat; kesepakatan mereka yang mengikatkan dirinya,kecakapan untuk membuat suatu perikatan,suatu pokok persoalan tertentu,suatu sebab yang tidak terlarang.

Jenis kontrak kerja menurut jenisnya ada 2 macam yaitu perjanjian waktu tertentu (PKWT) dan perjanjian kerja waktu tidak tertentu (PKWTT). Dalam prakteknya perusahaan sering mempekerjakan pekerja sebelum dibuat kontra atau belum menanda tangani kontrak atau perjanjian kerja, meskipun demikian karena pekerja sangat membutuhkan pekerjaan tersebut untuk memenuhi kebutuhan keluarga atau pekerja sendiri membuat pekerja menerima atau bersedia melakukan pekerjaan dengan harapan pengusaha dapat bersikap adil dalam memenuhi kewajibannya terhadap pekerja. Misalkan membayar

\footnotetext{
${ }^{1}$ Abdul Khakim, 2003, Pengantar Hukum Ketenagakerjaan Indonesia, Berdasarkan Undang-undang Nomor 13 Tahun 2003, Bandung: PT Citra Aditya Bakti, hal. 48.
} 


\section{PATIK : JURNAL HUKUM Vol : 09 No. 1, April 2020, Hal 1 - 9}

upah berdasarkan undang-undang yang berlaku dan jika pengusaha memperlakukan pekerja dengan baik meskipun tanpa kontrak bagi pekerja tidak ada masalah tetapi jika pengusaha tidak membayar upah karena tidak ada kontrak jadi hal ini dapat menjadi masalah bagi pekerja demikian hal nya dalam PT. Mendjangan J1. Setia Luhur 168, Dwikora, Medan dimana dalam PT tersebut pekerja yang telah melakukan pekerjaan belum menanda tangani kontrak namun pekerja tersebut menerima upah yang diberikan oleh pengusaha.

Dalam hukum ketenagakerjaan telah mengatur bahwa suatu hubungan kerja tanpa adanya status perjanjian kerja maka hal tersebut sudah bertentangan dengan pasal $50 \mathrm{UU}$ No. 13 Tahun 2003 Tentang Ketenagakerjaan dimana diisyaratkan dalam pasal tersebut bahwa " Hubungan kerja terjadi karena adanya perjanjian kerja antara pengusaha dan pekerja buruh.

Berdasarkan latar belakang diatas, maka perumusan masalah yang akan dibahas dalam penelitian ini yaitu:

1. Bagaimanakah status pekerja pada PT Mendjangan yang belum mengikat kontrak kerja tetapi sudah bekerja menurut UU No.13 Tahun 2003?

2. Bagaimanakah hak-hak pekerja pada PT Mendjangan yang belum mengikat kontrak tetapi sudah bekerja menurut UU No.13 Tahun 2003?

\section{Tinjauan Pustaka}

Perusahaan adalah istilah ekonomi yang dipakai dalam KUHD, namun dalam KUHD sendiri tidak menjelaskan secara resmi istilah perusahaan tersebut. Definisi perusahaan sendiri secara resmi dirumuskan dalam pasal 1 Undang-Undang Nomor 3 Tahun 1982 tentang Wajib Daftar Perusahaan"Setiap bentuk usaha yang menjalakan setiap jenis usaha yang bersifat tetap, terus-menerus, dan didirikan, bekerja serta berkedudukan dalam wilayah negara Indonesia dengan tujuan memperoleh keuntungan atau laba"

Sebelum ketentuan undang-udaang ini, tidak dijumpai defisini perusahaan, oleh karena itu para penulis hukum berusaha merumuskan definisi perusahaan berdasarkan pengetahuan yang mereka peroleh secara empiris ${ }^{2}$. Definisi lain perusahaan menurut Pasal 1 butir 1 Undang-Undang Nomor 8 Tahun 1997 tentang Dokumen Perusahaan yang berbunyi: "Perusahaan adalah setiap bentuk usaha yang melakukan kegiatan secara tetap dan terus menerus dengan memperoleh keuntungan dan atau laba, baik yang diselenggarakan oleh orang perorangan maupun badan usaha yang berbentuk badan hukum atau bukan badan hukum, yang didirikan dan berkedudukan dalam wilayah negara Republik Indonesia"

Sedangkan menurut Molengraaff mengenai defenisi perusahaan adalah sebagai berikut"Perusahaan adalah keseluruhan perbuatan yang dilakukan secara terusmenerus, bertindak keluar, untuk memperoleh penghasilan, dengan cara memperdagangkan atau menyerahkan barang atau mengadakan perjanjian perdagangan."

Pengertian perusahaan menurut Molengraaff tidak menekankan perusahaan sebagai sebuah badan usaha, melainkan hanya menyebutkan perusahaan sebagai sebuah kegiatan atau hanya terkhusus pada jenis usaha saja. Walaupun dalam pengertian tersebut telah memiliki aspek hukum perusahaan yaitu berupa perjanjian dengan pihak lain ${ }^{3}$

\footnotetext{
${ }^{2}$ Abdulkadir Muhammad, Hukum Perusahaan Indonesia, (Bandung, PT Citra Aaditya Karya Bakti:2010) hal.7

${ }^{3}$ Ibid, hal.8
} 


\section{PATIK : JURNAL HUKUM Vol : 09 No. 1, April 2020, Hal 1 - 9}

Berdasarkan definisi perusahaan yang dikemukakan oleh Molengraaf, dan pembentuk undang-undang, Abdulkadir Muhammad merumuskan defenisi perusahaan sebagai berikut: "Perusahaan adalah setiap badan usaha yang menjalankan kegiatan dalam bidang perekonomian secara terus-menerus, bersifat tetap, dan terang-terangan dengan tujuan memperoleh keuntungan dan atau laba yang dibuktikan dengan catatan (pembukuan)",4

Berdasarkan pengertian perseroan terbatas menurut UndangUndang Nomor 40 Tahun 2007 tentang Perseroan Terbatas, dapat disimpulkan prinsip umum sebuah perseroan yaitu:

a) Merupakan persekutuan modal, perseroan sebagai badan hukum memiliki modal dasar yang disebut juga authorized capital, yakni jumlah modal yang disebutkan atau dinyatakan dalam Akta Pendirian atau AD Perseroan

b) Didirikan berdasarkan perjanjian, perseroan sebagai badan hukum, didirikan berdasarkan perjanjian

c) Melakukan kegiatan usaha Sesuai dengan ketentuan Pasal 2 Undang-Undang Nomor 40 Tahun 2007 tentang Perseroan Terbatas, suatu perseroan harus mempunyai maksud dan tujuan serta kegiatan usaha.

d) Lahirnya perseroan melalui proses hukum dalam bentuk pengesahan pemerintah, lahirnya perseroan sebagai badan hukum (rechtspersoon, legal entity), karena diwujudkan melalui proses hukum (created by legal process) sesuai dengan ketentuan peraturan perundang-undangan.

Dari beberapa definisi atau pengertian di atas dapat dikatakan bahwa perseroan terbatas merupakan sebuah entitas badan hukum (recht persoon) yang wajib melakukan adaptasi sosio kultural dengan lingkungan tempatnya berada dan juga dapat dimintai pertanggungjawaban layaknya subjek hukum pada umumnya. Sebagai badan hukum, perseroan terbatas merupakan personifikasi manusia sebagai subjek hukum (naturlijk persoon $)^{5}$.

Pengertian tenaga kerja menurut Undang-Undang No.13 Tahun 2003 tentang Ketenagakerjaan diatas sejalan dengan pengertian tenaga kerja menurut konsep ketenagakerjaan pada umumnya sebagaimana ditulis oleh Payaman J.Simanjuntak (1985 :2) bahwa pengertian tenaga kerja atau manpower adalah mencangkup penduduk yang sudah bekerja, yang sedang mencari pekerjaan dan yang melaksanakan kegiatan lain seperti bersekolah dan mengurus rumah tangga. ${ }^{6}$ Pengertian tenaga kerja dan bukan tenaga kerja menurutnya ditentukan oleh umur/usia. Tenaga kerja atau manpower terdiri atas angkatan kerja dan bukan angkatan kerja.

Angkatan kerja (labour force) adalah penduduk usia produktif yang berusia 15-64 tahun yang sudah mempunyai pekerjaan tetapi sementara tidak bekerja, maupun yang sedang aktif menvari pekerjaan. Sedangkan bukan angkatan kerja adalah mereka yang berumur 10 tahun ke atas yang kegiatannya hanya bersekolah, mengurus rumah tangga dan sebagainya.

Selanjutnya jika ditelusuri tentang pengertian tenaga kerja yang telah di kemukakan diatas maka penulis dapat memahami bahwa tenaga kerja itu adalah individu yang sedang mencari atau sudah melakukan pekerjaan yang menghasilkan barang atau jasa yang sudah memenuhi persyaratan ataupun batasan usia yang telah ditetapkan oleh Undang-Undang yang bertujuan untuk memperoleh hasil atau upah untuk kebutuhan hidup sehari-hari.

\footnotetext{
${ }^{4}$ Abdulkadir Muhammad, op, cit. Hal.13

${ }^{5}$ Ibid hal 33-38

${ }^{6}$ Lalu Husni “Hukum Ketenagakerjaan Indonesia”, PT. Raja Grafindo Persada, Jakarta, 2007, hlm.15-16
} 


\section{PATIK : JURNAL HUKUM Vol : 09 No. 1, April 2020, Hal 1 - 9}

\section{Metode}

Adapun yang menjadi ruang lingkup penelitian ini adalah sebatas mengenai status pekerja yang belum mengikat kontrak kerja dan hak-hak pekerja yang belum mengikat kontrak kerja tapi sudah bekerja. Dalam penyusunan Penelitian inidata yang digunakan adalah data primer yang diperoleh langsung di lapangan dan sekunder yaitu data yang sudah ada dan tersedia di kepustakaan. Data sekunder bersumber dari bahan hukum yaitu: Bahan hukum primer adalah bahan hukum yang mempunyai otoritas. Bahan hukum tersebut terdiri dari peraturan perundang-undangan, catatan resmi atau risalah dalam pembuatan suatu peraturan perundang-undangan, dan putusan hakim. ${ }^{7}$

Alat pengumpulan data yang digunakan dalam mengkaji permasalahan Penelitian ini adalah : Metode penelitian kepustakaan adalah metode penelitian yang dilakukan diperpustakaan, dimana data yang diperoleh dengan cara membaca, mempelajari bukubuku, dokumen, peraturan-peraturan per Undang-undangan, karya ilmiah, makalah, internet dan dokumen lain yang ada kaitannya dengan Penelitian ini. Metode penelitian lapangan adalah, Suatu penelitian yang dilakukan secara sistematis dengan mengangkat data yang ada dilapangan. Data yang diperoleh dengan cara wawancara dengan Novarianti Sitio jabatan Personalia

Dalam suatu penelitian analisis data meupakan suatu tahap yang sangat penting, dalam penelitian ini metode analisis data yang digunakan adalah metode analisis kualitatif. Analisis kualitatif adalah upaya yang dilakukan dengan jalan bekerja dengan data, mengorganisasikan data, memilah-milahnya menjadi satuan yang dapat dikelola, mensintesiskannya, mencari dan menemukan pola, menemukan apa yang penting dan apa yang dipelajari dan memutuskan apa yang dapat diceritakan kepada orang lain. Kemudian data yang diperoleh disusun secara sistematis sehingga didapat gambaran yang komprehensif. Selanjutnya ditarik satu kesimpulan yang dituangkan dalam bntuk tulisan yang berasal dari studi kepustakaan dan didukung dengan studi lapangan sehingga doperoleh peneilitian yang bersifat deskriptif. ${ }^{8}$

\section{Pembahasan Dan Hasil}

Bertumbuhnya PT Mendjangan membuat perusahaan memperluas jangkauannya ke bisnis sejenis pada tahun 1987. Mendjangan Group menawarkan layanan marketing, manufaktur, dan distribusi terakselerasidengan meningkatkan kualitas hidup melalui solusi kesehatan yang dapat diakses siapa punmelalui berbagai macam kegiatan, seperti:Impor dan perdagangan bahan baku untuk industri farmasi, kosmetik, bahan pangan, dan pakanProduksi produk farmasi dan konsumsi, Distribusi pemasaran secara internasionalMemproduksi dan memasok alat-alat kesehatan dan dental equipment, Memasok perlengkapan medis/farmasi dan distribusi barang konsumsi bisnis di bidang kesehatan atau bisnis farmasi online

Berkat ketekunan dan kerja keras, PT Mendjangan mendapatkan sebuah kehormatan untuk dipercaya lembaga dunia, termasuk bekerja sama dengan beberapa rekanan/pemasok utama (principal) kelas dunia. Pertumbuhan stabil dari tahun ke tahun inilah yang memungkinkan perusahaan untuk melakukan perluasan dan diversifikasi bisnis.

Filosofi PT Mendjangan ialah tetap berkomitmen menjaga nilai bisnis, seperti kepercayaan, kredibilitas, dan kedisiplinan. Di masa mendatang, PT Mendjangan

\footnotetext{
${ }^{7}$ Prof.Dr.H.Zainuddin Ali, Metode Pnelitian Hukum,(Jakarta:Sinar Grafika,2009),hal.47.

${ }^{8}$ M. Nazli, Metode Penelitian, Ghalia Indonesia, Jakarta, 2010, hal.111
} 


\section{PATIK : JURNAL HUKUM Vol : 09 No. 1, April 2020, Hal 1 - 9}

berkomitmen untuk menjadikan diri kami sebagai perusahaan bisnis di bidang kesehatan dan lini bisnis utama lainnya di Indonesia yang mengutamakan riset dan pengembangan, perbaikan kegiatan marketing terus-menerus (meningkatkan kerja sama strategis), dan saluran distribusi.

Nilai - Nilai inti dalam PT Mendjangan ialah menjaga komitmen yang dimana komitmen adalah jangkar kami. Kami percaya, kekuatan kami dalam memegang teguh komitmen akan menciptakan pemahaman yang baik dalam bekerja sama dan membawa kami menuju tahap selanjutnya dalam sebuah bisnis. Mengutamakan hubungan kerja yang seimbang dan berjangka panjang dimana memiliki hubungan kerja yang professional dan berjangka panjang dengan rekanan bisnis kami sehingga menjadikan perusahaan tepercaya dibidang kesehatan. Mengembangkan inovasi sebagai salah satu perusahaan terbaik. PT Mendjangan berkeinginan secara konsisten untuk memberikan inovasi baru dalam bidang kesehatan. Berusaha menjadi yang terbaik PT Mendjangan selalu mengupayakan untuk menjadi perusahaan terbaik disegani di dunia dalam bidang kesehatan. Memastikan perbaikan yang berkesinambungan Secara berkelanjutan PT Mendjangan terus melakukan perbaikan pada setiap aspek untuk meningkatkan kualitas hidup melalui solusi kesehatan yang dapat diakses dengan mudah.

Berdasarkan wawancara yang penulis lakukan di PT Mendjangan Jl. Setia Luhur dengan Sdri Novarianti Sitio status pekerja sudah sesuai dengan ketentuan UndangUndang Ketenagakerjaan No.13 Tahun 2003 dan KUH Perdata. Status pekerja yang ada di PT Mendjangan terbagi atas 3 dasar perjanjian yaitu Perjanjian Kerja Waktu Tidak Tertentu (PKWTT) dimana karyawan/pekerja PKWTT dipekerjakan untuk jenis pekerjaan yang sifatnya tetap dan terus-menerus. Perjanjian kerja tidak dibatasi oleh jangka waktu. Kecuali terjadi PHK, hubungan kerja antara pengusaha dan pekerja hanya berakhir ketika pekerja memasuki usia pensiun, meninggal dunia, cacat atau sakit permanen dan tidak mampu lagi bekerja, atau kondisi lain yang disebutkan dalam perjanjian. Pekerja PKWTT disebut juga karyawan tetap.PKWTT dapat dibuat secara tertulis maupun lisan, dan dapat mensyaratkan masa percobaan (probation) paling lama 3 bulan.

Perjanjian Kerja Waktu Tertentu (PKWT) karyawan/pekerja PKWT dipekerjakan untuk jenis pekerjaan yang sifatnya sementara, sekali selesai, pekerjaan musiman, atau terkait produk baru yang masih dalam percobaan. Karyawan PKWT tidak dapat dipekerjakan untuk pekerjaan yang sifatnya tetap dan terus menerus. PKWT dibatasi oleh jangka waktu atau masa berlaku kontrak. Hubungan kerja antara pengusaha dan pekerja otomatis berakhir apabila jangka waktu perjanjian berakhir atau pekerjaan selesai. Pekerja PKWT disebut juga karyawan kontrak. PKWT wajib dibuat secara tertulis dalam Bahasa Indonesia dan huruf latin, dan tidak dapat mensyaratkan masa percobaan. Apabila kontrak berakhir, maka karyawan tidak berhak atas uang pesangon. Namun, apabila salah satu pihak mengakhiri hubungan kerja di tengah masa kontrak, maka ia wajib membayar ganti rugi sebesar upah sisa masa kontrak. Dan ada juga pekerja/buruh harian lepas dimana pekerja/buruh harian lepas ini sistem musiman atau sementara dan sistem gaji harian.

Namun di PT Mendjangan sendiri masih ada tenaga kerja yang belum jelas mengenai status pekerja itu sendiri, dimana pekerja tersebut karena butuh nya pekerjaan tersebut untuk memenuhi kebutuhan keluarga atau pekerja sendiri membuat pekerja menerima atau bersedia melakukan pekerjaan dengan harapan pengusaha dapat bersikap adil dalam memenuhi kewajibannya terhadap pekerja.

Dan bagaimana status pekerja apabila belum mengikat kontrak kerja tetapi sudah bekerja dan menerima upah apakah status pekerja tersebut dapat disamakan dengan pekerja yang telah mengikat kontrak kerja. Dalam wawancara penulis dengan Sdri Novarianti Sitio terhadap PT Mendjangan, pekerja tersebut sudah termasuk ke dalam pekerja harian lepas. 


\section{PATIK : JURNAL HUKUM Vol : 09 No. 1, April 2020, Hal 1 - 9}

Yang membedakan buruh harian lepas dengan yang lain adalah kerja sebulannya sepuluh (10) hari saja tidak full 1 bulan, pemberian upahan berdasarkan hari mereka kerja dan status nya saja. Buruh harian lepas berdasarkan kebutuhan yang ada dilapangan dan tidak termasuk dalam daftar list karyawan perusahaan. Dan di dalam Keputusan Menteri No.100 Tahun 2004 merupakan peraturan pelaksanaan dari Undang-Undang Ketenagakerjaan (UUK) mengenai PKWT, yang didalamnya juga mengatur mengenai Perjanjian Kerja Harian Lepas. Dengan demikian, perjanjian kerja harian lepas menurut KEPMEN merupakan bagian dari PKWT.

Berdasarkan wawancara dengan Sdri Novarianti Sitio dan pengamatan Pada PT Mendjangan Setia Luhur Dwikora Medan , mengenai hak-hak pekerja sudah sesuai dengan Undang-Undang No.13 Tahun 2003. Yang membedakan hak pekerja di PT tersebut adalah pekerja yang menurut perjanjian kerja nya yaitu Perjanjian Kerja Waktu Terntentu dan Perjanjian Kerja Waktu Tidak Tertertu, Buruh Harian Lepas.

Dan bagaimana hak-hak pekerja yang belum mengikat kontrak kerja tetapi sudah bekerja pada masalah 1 dikatakan bahwa pekerja tersebut termasuk dalam buruh harian lepas. Di dalam PT Mendjangan upah pekerja harian lepas dapat ditetapkan berdasarkan dua skema, yaitu berdasarkan waktu dan berdasarkan hasil. Dalam mempekerjakan pekerja harian lepas tidak bisa dilakukan secara terus-menerus. terdapat batas waktu yang mengatur, yaitu maksimal 21 hari dalam satu bulan. Jika pelaksanaannya 21 hari atau lebih selama 3 bulan berturut-turut, maka status pekerja berubah menjadi karyawan tetap. Namun di PT Mendjangan mempekerjakan pekerja harian lepas hanya 10 hari saja. Meski dalam praktiknya perjanjian kerja ini dapat diperpanjang atau diperbaharui namun berdasarkan aturan dalam UU No 13 Tahun 2003, perusahaan tidak bisa memberikan status PKWT pada semua jenis pekerjaan. Dan kontrak kerja Perjanjian Kerja Tidak Tertentu maupun Perjanjian Kerja Waktu Tertentu setiap karyawan mendapatkan hak-hak yang berbeda dan yang membedakan PKWT dan PKWTT adalah

1) Dalam PKWT waktu dibatasi atau selesainya pekerjaan, PKWTT tidak ada batasan waktu hingga usia pensiun atau pekerja meninggal dunia

2) Dalam PKWT phk demi hukum (otomatis batal secara hukum) sesuai dengan yang tertera dalam perjanjian, tidak harus melalui proses LPPHI. PKWTT phk karena alasan tertentu, harus melalui proses LPPHI (Lembaga Penyelesaian Perselisihan Hubungan Industrial)

3) Kewajiban ketika phk dalam PKWT phk sesuai dengan waktu yang diperjanjikan, tidak ada kewajiban perusahaan membayar uang pesangon dan uang penghargaan masa kerja terjadi. Terjadinya phk dalam PKWTT, pengusaha wajib memberikan pembayaran (kecuali pada PHK tertentu)

4) Dalam masa percobaan PKWT tidak boleh ada masa percobaan. Bila diberlakukan, masa percobaan batal demi hukum (batal otomatis secara hukum). Sedangkan dalam PKWTT Masa percobaan diperbolehkan

5) Dalam kontrak kerja PKWT perjanjian kerja harus tertulis dengan huruf latin, dalam bahasa Indonesia. PKWTT perjanjian kerja bisa tertulis atau lisan

6) Dalam pencatatan PKWT wajib dicatatkan di instansi ketenagakerjaan. PKWTT tidak wajib dicatatkan

Dari penulis wawancari dari Sdri Novarianti Sitio yang membedakan pekerja tersebut hanya status kepegawaian, dan untuk Perjanjian Kerja Waktu Tertentu tenggang waktu kerja dibatasi oleh pihak pengusaha dan karyawan, dan apabila batas waktu kontrak 


\section{PATIK : JURNAL HUKUM Vol : 09 No. 1, April 2020, Hal 1 - 9}

telah berakhir maka berakhirlah masa kerja pekerja tersebut. Buruh harin lepas bekerja hanya 10 hari saja, sistem upah perhari dan status mereka saja yang membedakan. Dan

perlindungan terhadap Hak-Hak pekerja di PT Mendjangan sudah sesuai dengan peraturan Undang-Undang Pasal 27 ayat 2 yang berbunyi "Tiap-tiap warga negara berhak atas pekerjaan dan penghidupan yang layak bagi kemanusiaan".

PT. Mendjangan dalam memberikan upah tidak ada diskriminasi terhadap para pegawainya atau pekerjanya. Semua diberikan pengupahan tersebut sesuai dengan bagian dan kesepakatan kerja awal. Dan waktu kerja di PT Mendjangan sudah sesuai dengan Pasal 77 ayat 2 Undang-Undang Nomor 13 Tahun 2003 tentang Ketenagakerjaan yang mengatur tentang ketentuan waktu kerja yaitu 8 (delapan) jam 1 (satu) hari dan 40 (empat puluh) jam 1 (satu) minggu untuk 5 (lima) hari kerja dalam 1 (satu) minggu.

Dan untuk waktu Istirahat pada PT Mendjangan sudah sesuai dengan ketentuan Undang-Undang yang berlaku misalkan istirahat mingguan, waktu istirahat ini menurut ketentuan Undang-undang Nomor 13 Tahun 2003 tentang Ketenagakerjaan pasal 79 tentang istirahat mingguan adalah waktu istirahat 1 hari untuk 6 hari kerja dalam 1 minggu atau 2 hari untuk 5 hari kerja dalam 1 minggu. Pada PT Menjangan diberikan istirahat mingguan 1 hari dalam waktu 1 minggu kerja diberi pada hari minggu untuk pekerja.

Untuk tunjangan hari raya keagamaan yang selanjutnya disebut THR perusahaan wajib memberikan THR kepada pekerja yang telah mempunyai masa kerja 3 bulan secara terus menerus atau lebih. Sesuai permenaker No. 4 Tahun 1994 tanggal 16 September 1994 mengatur tentang Tunjangan Hari Raya (THR) diterima pekerja setiap tahun sekali, yakni pada saat melaksanakan hari raya keagamaan masing-masing.

Dalam hal pemberian tunjangan hari raya, PT Mendjangan memberikan tunjangan tersebut kepada setiap para pekerja karena mereka sudah terikat kontrak kerja yang lama kerjanya mencapai 1 tahun. Tunjangan hari raya ini diberikan sebesar 1x gaji pokok perbulan. Seperti hasil wawancara penulis dengan PT Mendjangan,membayar THR kepada para pekerja dibayar paling lambat 7 hari sebelum hari raya keagamaan. Tunjangan Hai Raya tidak sepenuhnya diberikan dalam bentuk uang tetapi sebagian dibelanjakan barang yang berupa sembako.

\section{Kesimpulan Dan Saran}

Pada status tenaga kerja di PT Mendjangan masih ada yang tidak jelas status nya dimana pekerja tersebut bekerja tanpa melihat status dia sendiri yang artinya pekerja tersebut bekerja tanpa status dan hanya menerima upah. Dan pertanggung jawaban dari pihak perusahaan itu sendiri ialah status pekerja tersebut diangkat status nya/masuk kedalam pekerja/buruh harian lepas. Dimana PT Mendjangan, tidak mau nanti nya atau kedepannya terjadi masalah terhadap pekerja yang belum mengikat kontrak kerja tersebut dan akan menjadi polemic di perusahaan tersebut.

Pihak PT Mendjangan Jl. Setia Luhur Dwikora Medan merupakan salah satu perusahaan yang telah menjalakan ketentuan undang-undang dimana setiap pekerja mendapatkan hak yang sama sesuai dengan Undang-undang dan tidak ada perbedaan hakhak yang membedakan hanyalah status kepegawaian atau jenis pekerja. Hak-hak kepegawaian/tenaga kerja yang status nya sudah jelas atau sudah masuk dalam perjanjian tenaga kerja sudah sesuai dengan Undang-undang No. 13 tahun 2003 baik itu PKWT/PKWTT dan untuk hak-hak pekerja yang hak-hak nya tidak jelas/ belum menandatangani kontrak kerja atau perjanjian kerja pihak PT Mendjangan menaikan status pekerja tersebut ke dalam buruh harian lepas dan agar hak-hak nya jelas dan tidak ada masalah nantinya kedepan nya. Di dalam Kepmen No.100 tahun 2004 mengenai PKWT, 


\section{PATIK : JURNAL HUKUM Vol : 09 No. 1, April 2020, Hal 1 - 9}

didalam nya mengatur juga mengenai buruh harian lepas, perjanjian kerja harian lepas menurut KEPMEN merupakan bagian dari PKWT.

Didalam mempekerjakan tenaga kerja PT Mendjangan sebaiknya tidak lagi mempekerjakan pekerja tanpa perjanjian kerja atau kontrak kerja dikarenakan bila terjadinya suatu masalah ke depannya pada tenaga kerja tersebut akan menjadi masalah bagi perusahaan itu sendiri. Dan dikarenakan sudah diatur dalam Undang-undang No.13 tahun 2003 tentang ketenagakerjaan dimana pekerja harus lah ada status pekerja nya/ perjanjian kerja nya baik itu pekerja dengan pengusaha. Dan pihak PT Mendjangan juga bergerak cepat dalam masalah tersebut dimana pekerja tersebut status nya dinaikkan menjadi buruh harian lepas dan sudah termasuk dalam perjanjian kerja waktu tertentu.

\section{DAFTAR PUSTAKA}

\section{BUKU}

Abdul Khakim, 2003, Pengantar Hukum Ketenagakerjaan Indonesia, Berdasarkan Undang-undangNomor 13 Tahun 2003, Bandung: PT Citra Aditya Bakti, hal. 48.

Abdulkadir Muhammad, Hukum Perusahaan Indonesia, (Bandung, PT Citra Aaditya Karya Bakti:2010) hal.7

Chidir Ali, Badan Hukum, (Bandung: P.T. Alumni, 2011) hal.110

Abdulkadir Muhammad, op, cit. Hal.13

Abdulkadir Muhammad, op, cit, hal 84

M. Yahya Harahap, Hukum Perseroan Terbatas, (Jakarta: Sinar Grafika, 2009), hal. 21.

H.M.N. Purwosutjipto dalam Yahya Harahap, Ibid., h. 22

Lalu Husni, Pengantar Hukum Ketenagakerjaan Indonesia, (Jakarta: RajaGrafindo, 2008) h. 33

Lalu Husni, Pengantar Hukum Ketenagakerjaan Indonesia, (Jakarta, Raja Grafindo Persada, 2000), Edisi Revisi, hal. 33-35

Iman Soepono, 2007. "Pengantar Hukum Perburuhan”, Jakarta. Djambatan Hal. 55

Salim, HS, "Perkembangan hukum jaminan di Indonesia", 2007, Jakarta, Raja Grafindo Persada, Hal. 57

Koko Kosidin 2002. "Perjanjian kerja, Perjanjian Perburuhan dan Peraturan Perusahaan". Bandung: Mandar Maju. Hal. 4

Iman Soepono, 2007. "Pengantar Hukum Perburuhan”, Jakarta. Djambatan Hal. 55

Wiwoho Soedjono, 2003. "Hukum Perjanjian Kerja”, Jakarta.Bina Aksara, Hal. 9.

Lalu Husni, 2000. "Pengantar Hukum Tenaga Kerja Indonesia". Jakarta: Raja Grafindo Persada. Hal. 51

Prof.Dr.H.Zainuddin Ali, Metode Pnelitian Hukum,(Jakarta:Sinar Grafika,2009),hal.47.

M. Nazli, Metode Penelitian, Ghalia Indonesia, Jakarta, 2010, hal.111

\section{UNDANG-UNDANG}

Undang-Undang Nomor 13 Tahun 2003

Keputusan Menteri Nomor 150 Tahun 1999 Tentang Penyelenggaraan Program Jaminan Sosial Tenaga Kerja

Keputusan Menteri Nomor 100 Tahun 2004 